
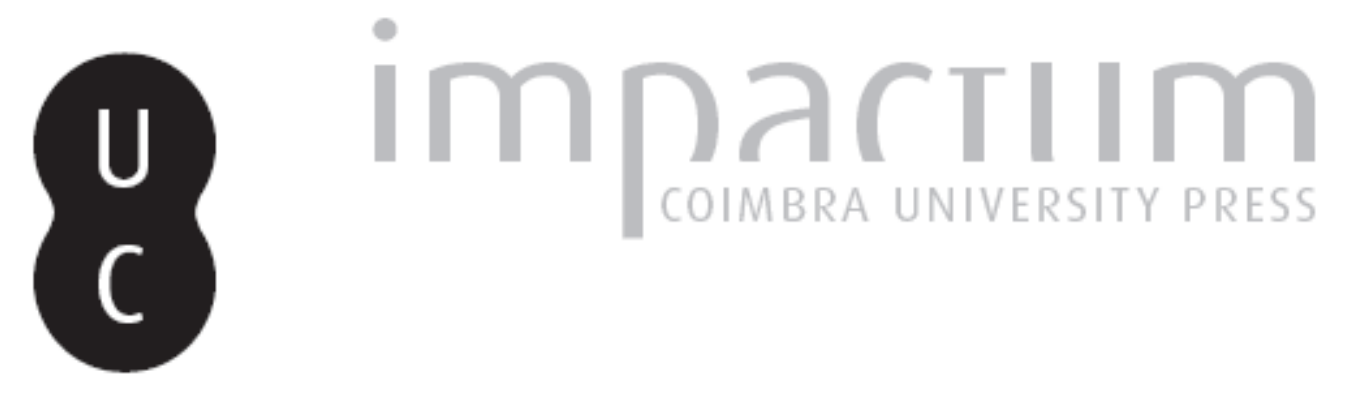

\title{
[Recensão a] N. S. Galgano, I Precetti della Dea: Non Essere e Contraddizione in Parmenide di Elea
}

\author{
Autor(es): $\quad$ Privitello, Lucio Angelo \\ Publicado por: Imprensa da Universidade de Coimbra; Annablume \\ URL \\ persistente: \\ URI:http://hdl.handle.net/10316.2/44820 \\ DOI: \\ DOI:https://doi.org/10.14195/1984-249X_25_11 \\ Accessed : $\quad$ 26-Apr-2023 05:21:01
}

A navegação consulta e descarregamento dos títulos inseridos nas Bibliotecas Digitais UC Digitalis, UC Pombalina e UC Impactum, pressupõem a aceitação plena e sem reservas dos Termos e Condições de Uso destas Bibliotecas Digitais, disponíveis em https://digitalis.uc.pt/pt-pt/termos.

Conforme exposto nos referidos Termos e Condições de Uso, o descarregamento de títulos de acesso restrito requer uma licença válida de autorização devendo o utilizador aceder ao(s) documento(s) a partir de um endereço de IP da instituição detentora da supramencionada licença.

Ao utilizador é apenas permitido o descarregamento para uso pessoal, pelo que o emprego do(s) título(s) descarregado(s) para outro fim, designadamente comercial, carece de autorização do respetivo autor ou editor da obra.

Na medida em que todas as obras da UC Digitalis se encontram protegidas pelo Código do Direito de Autor e Direitos Conexos e demais legislação aplicável, toda a cópia, parcial ou total, deste documento, nos casos em que é legalmente admitida, deverá conter ou fazer-se acompanhar por este aviso.

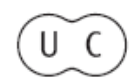




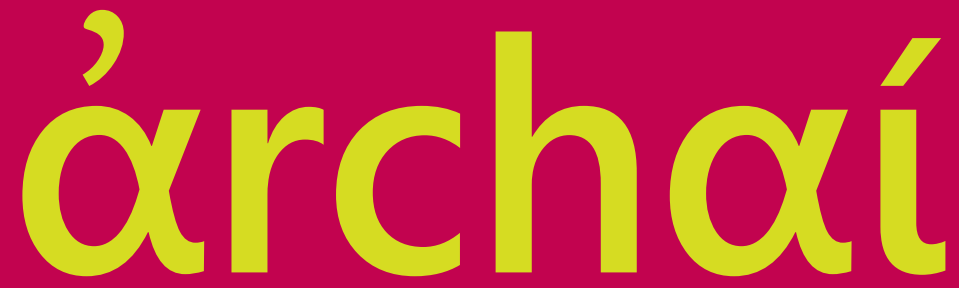

AS ORIGENS DO PENSAMENTO OCIDENTAL

THE ORIGINS OF WESTERN THOUGHT 


\title{
ảrchaí
}

AS ORIGENS DO PENSAMENTO OCIDENTAL

THE ORIGINS OF WESTERN THOUGHT

RESENHA I REVIEW

\section{N. S. Galgano, I Precetti della Dea: Non Essere e Contraddizione in Parmenide di Elea (2017, Diogene Multimedia)}

\author{
Lucio Angelo Privitello ${ }^{\mathrm{i}}$ \\ https://orcid.org/0000-0002-5875-6068 \\ lucioap57@outlook.com
}

\footnotetext{
${ }^{i}$ Stockton University - Galloway - NJ - USA

PRIVITELLO, L. A. (2019). N. S. Galgano, I Precetti della Dea: Non Essere e Contraddizione in Parmenide di Elea (2017, Diogene Multimedia). Archai 25, e02511.
} 
Nicola Stefano Galgano (2017), I Precetti della Dea: Non Essere e Contraddizione in Parmenide di Elea deserves to be seriously considered for translation into various languages. In this text, there resides a truly persuaded Parmenidean spirit, one that has lived by an inspired vision, while having demonstrated the courage, and measured craft in carving out its fortune. Due to its length and its conjectures, dutiful scholarship, and engagement with many studies and scholars of Parmenides, this admirable text also deserves a substantially longer critical-review, of which this can merely serve as a short preface. To my delight, Galgano realizes how discussions in Parmenidean scholarship can easily slip into fields of battle (Galgano, 2017, p. 216), and yet, even though Galgano has wounded, or tried to wound, more than a few theoretical positions, or details therein, and suffered his own wounds, his overall strategy remains "un discourse affidabile" (a trustworthy discourse) (Galgano, 2017, p. 207). With atremes etor, Galgano seeks to follow the maxims of the goddess.

Even though the field and subfields of Parmenidean studies receive careful tending, more than a few brambles, thorns, and brier impede the way to its fruits. The fields of battle of scholarship tend to proliferate their own ensnaring bittersweet vines and creepers. There is a tendency for this to hinder and haunt the very composition of scholarly texts, of which Galgano's is no exception. These texts become greater puzzles than what has remained of Parmenides' poem. Hope for a greater unanimity of interpretation (Galgano, 2017, p. 13) is impossible without first retranslating and resequencing the fragment citations. This applies to puzzles that are philosophical, purely textual-philological, or stylistic (Galgano, 2017, p. 28-29, 58). Galgano offers us some delightful and telling translations of various fragment lines, and the reader would hope for a full view of the poem. Though Galgano accepts and uses the DK order of the fragments (Galgano, 2017, p. 37, n. 22) with very few exceptions, he gives Diels-Kranz the lie by stating that the division of the poem in two parts (aletheia and doxa) is purely and superficially (and justly, I might add), a “didactic cliché” (Galgano, 2017, p. 102). However, Galgano then waivers. He sees the two parts of the poem as 
Parmenides' two separate responses to inherent human cognitive distortion (Galgano, 2017, p. 169). Galgano should follow this text with a new translation and sequence of Parmenides' poem.

A few irksome thorns are: under 2.5 Il frammento 4, on page 69, should read see 6.2 "Il frammento 4" page 189, not 187, but more importantly 2.5 should be expunged from the text. After 2.6.2 "I versi 6.4-9", the table of contents must include the important subsections and titles from 2.6.2.1 through 2.6.2.6. The same applies for the important subsections 3.2.4.1, "La meditazione del non essere" through 3.2.4.5 that follow section 3.2.4 "Il secondo cammino (versi 5-8)". Subsection 4.1.1.1 "I versi 6.3-4" is also missing from the contents page as is 4.2.2.1 "I versi 8.6b-7a", 4.2.2.2 "I versi 8.7b-9a", and 4.2.2.3, "Ripresa dei versi 8.7b-9a". The table of contents for part 6 also requires 6.1.2.1 "Versi 12 e 13a" that should read "Versi 8.12 e 13a" and the same would apply to 6.1.2.2, read "Versi 8.13b-15a", and 6.1.2.3 "Versi 8.15-18". While these editorial minutiae seem inconsequential, the puzzle pieces of a text should retain the utmost clarity in outline and comprehensiveness. As a final recommendation, and due to firmly believing in the worth of Galgano's text, and its hopeful lives in translation, or in a second Italian edition, there is need of a carefully crafted Index Locorum, Index of Authors, and a general index. These will greatly enhance the "cammino di ricerca” already provided.

Galgano's focus is found, and gains its fascination, from the Parmenidean theme of to me eon (that which is not). In tracking its many mentions through the poem, we confront the Eleatic aporia, and the object of the text, viz., to overcome the history of relegating non-being to a formal logic or linguistic operation, and instead to see it as the very condition of the possibility of contradiction and the foundational comportment of human cognitive behavior. Galgano claims that the turning away from investigating to me eon (that which is not) derives from Plato, who was the first to use and incorporate snippets of Parmenides' poem. Galgano was justly bewildered at the vastness of his undertaking when embarking on this thematic journey (Galgano, 2017, p. 23), and more so in framing Parmenides as the 
first psychologist (p. 26). Nietzsche must be turning in his grave. Galgano also states that Parmenides is "the philosopher of nonbeing" (Galgano, 2017, p. 109), and "invented the notion of non being” (Galgano, 2017, p. 163). At this point, the reader's lifeline appears taut between M. J. Henn's category of “ontophobia”, and a quasi-eastern function of nihilphilia. This is due to the chase after contradictions (oute phrasais) and negative definitions that will inevitably point (phrazō) back to the subject's cognitive operations; or more realistically, their juridical/social Ecce Animus from the impasse of living in-nots (Galgano, 2017, p. 131, n. 143, and p. 132).

Present in Galgano's text is a highly speculative example of comparative philosophy that sneaks in (and is then brushed off) due to having sidestepped the everyday position of Parmenides as legislator, and healer to his Elean community. As a deeply respected lawgiver (in the spirit of Solon, Cadrondas, or Zaleucus), Parmenides would have plenty of examples, (and was an awesome example), with no need to import something new from the Chāndogya Upaniṣhad, to teach an Elean kouros of their social and juridical duties in trustworthy speech (Galgano, 2017, p. 151-153, 163, n. 163, p. 207). The realism Galgano is after is a social ontology, more than a gnosiological realism, or even a cosmology, and this is mentioned, but quickly glossed over, as "la dignità esistenziale di ogni essere, il che impone l'impossibilità di eliminare qualunque essere, anche quello che si giudica - in un modo o nell'altro, a torto o a ragione..." (the existential dignity of every being, that sets the impossibility to eliminate any being, even one which is judged - in one way or the other, whether wrong or right) (Galgano, 2017, p. 166). Here we see the hard kernel (zoccolo duro), and distinctive isonomy of Parmenides' approach, and perhaps the very reason for the poem's existence, and a page out of the book of the concrete everydayness of a social setting. Parmenides' poem has a pre-Epicurean undertone to it from being directed at his community as a way to secure conviction in their social/cultural setting, and the world/phenomena around them, while remaining free from the disturbance of contrived unthinkable paths and hearsay. Galgano timidly gestures towards this, but overlooks it in his otherwise very commendable text 
(Galgano, 2017, p. 91, 171, 177-178, 213), and his own lived and supported "quotidianità dello sviluppo della ricerca del libro" mentioned on page 216. This would have answered Galgano's search for the possibility of "un altra struttura cognitive" (Galgano, 2017, p. 177-178). Look no further than to the social/cultural being, and that would in turn answer to "natural", "super-natural", and cognitive eccentricities (p. 178). This is how the three precepts of the goddess (Galgano, 2017, p. 213) return as one, for "it is all the same/ from where I begin; from there I return back again” (DK 5.1-2, best placed as fragment 2).

What presents a deeper problem (inciting further rereading of the text) is Galgano's view of Parmenides as psychologist. On a trivial level, of course he was. On a more profound level, certainly, but as an iatromantis. Recall, "Parmenide figlio di Pyrês, Ouliadês, medico"; sounds more Freudian with a touch of Rank, Jung, or Reik, if anything. Yet, it is not clear, nor explained in any detail, what type of cognitive psychology, or "cognitive operations", (which is Galgano's favorite and overused nomenclature), is at stake (Galgano, 2017, p. 84, 86-88, 92-93, 98, 179, 192, 210). Cognitivist? No individual can internalize a total system of language, and this problematizes nativism. A system (or operation) is only lived as consensual practices by an entire society, culturally acquired and emergent over time, and afterwards merely approximated by idealized theories in a general heuristic sense. Galgano does not point out what specific innate capacities are acquired, save perhaps the most basic laws of logic (Galgano, 2017, p. 168-177). The term polypeiron points in a direction of cultural and socially acquired experiences, and should be further pursued (Galgano, 2017, p. 85, n. 88-89, and p. 86), and might even lead to an actual direction in a specific cognitivist methodology known as pattern recognition. In all, very general mentions on psychology are present throughout the text, beginning on page 14 , through to page 100 , then disappearing until page 168, and again mentioned up until page 210. There Galgano states that Parmenides the psychologist would "probably be what we today call cognitivist”. Unlikely. All this is very unhelpful without actual details as to issues of attention, memory, consciousness, 
perception, and thinking. To substitute "operare cognitivamente" for noein does not cut the muster (Galgano, 2017, p. 70). We are not sure if Galgano is pointing towards an extreme, moderate, or a cognitivist position at all. Perhaps Galgano is wrestling with Parmenides as a social psychologist, but not enough is given to the reader for that methodology. We might be able to dig out some examples of cognitively innate (and unavoidable) competence from what Galgano presents from crucial terms in Parmenides fragment 6, that follow chapter 2.6.2 "I versi 6.4-9. Yet, could these not be purely socially acquired conceptual abilities, or social contingencies of language acquisition? How particular and extensive are these possible innate competences? This would jeopardize, or at least problematize, any robust cognitivist or nativist reading.

Engaging these mentions would require a substantially longer, and more detailed critical review. What remains to be questioned, and then developed by Galgano (as if he has not done enough already), is his claim that his is a study on the "psychology" in the work of Parmenides (Galgano, 2017, p. 26, 34-35, 39, 50, 70) that has not been previously undertaken in a sustained manner. We must then ask Galgano for a clear and distinct list of what he calls a "vocabolario psicologico” (Galgano, 2017, p. 68, 71, 83, 194). Without this list, we remain without the resources (amēchaniē) to conclude anything about Parmenides as psychologist. More than a cognitivist approach, the readings of specific terms, and fragments, especially fragment 6 , could lead to an even more radical Lacanian approach, and stepping through the snares, registers and knots of the Imaginary, the Symbolic, and the Real (Galgano, 2017, p. 69-81). However, Lacan would side with Heraclitus. In all, Parmenidean studies is lucky to have Galgano on their side as a valiant scholar in the field.

\section{Bibliography}

GALGANO, N. S. (2017). I Precetti della Dea: Non Essere e Contraddizione in Parmenide di Elea. Bologna, Diogene Multimedia. 
Submitted in 19/08/2018 and accepted for publication 01/09/2018

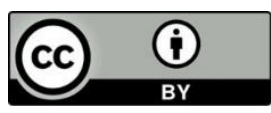

This is an Open Access article distributed under the terms of the Creative Commons Attribution License, which permits unrestricted use, distribution, and reproduction in any medium, provided the original work is properly cited. 